\title{
Allied and Alienated: Landscape in Seamus Heaney's Early Poetry
}

\author{
Yaorong $\mathrm{He}^{1}$ \\ ${ }^{1}$ College of International Studies, Southwest University, Chongqing, China \\ Correspondence: Yaorong He, College of International Studies, Southwest University, Beibei Distirct, \\ Chongqing, China. Tel: 86-188-8325-3596. E-mail: heyaorong1004@163.com
}

Received: October 7, 2014 Accepted: October 27, 2014 Online Published: November 25, 2014

doi:10.5539/ells.v4n4p79

URL: http://dx.doi.org/10.5539/ells.v4n4p79

\begin{abstract}
Landscape is prevalently presented in early poetry of Seamus Heaney in the forms of landscape of natural ecology, farm practices and place-names. The landscape description is not only a way of nostalgia for the disappearing Irish natural scenes, but also contributes to deal with writer's relationship with homeland and home culture, expressing his ambivalent feeling of being allied as well as alienated toward native traditional culture. Meanwhile, the landscape description is poetic transcendence as well as a retreat for Heaney to reconcile conflicts and keep a proper balance between artistic freedom and social responsibility.
\end{abstract}

Keywords: Seamus Heaney, early poetry, landscape, allied and alienated, retreat

\section{Introduction}

Poetry and painting have long related, intersected. In Ars Poetica (or "The Art of Poetry", Horace has put forward "ut pictura poesis" (or "as is painting so is poetry,") which means that poetry, in its widest sense is "imaginative texts", the same merits of interpretation that was in his day reserved for painting. Landscape is originally used in painting. The word "landscape" appeared in the early $17^{\text {th }}$ century. A dictionary of 1612 describes landtskip as a Dutch word, the suffix "-skip" corresponds to the English "-ship". Landtskip was a term in painting where nature was included generally "for the sake of something else." (Siddal, 2009, p. 16) Then, it was Gavin Douglas who established "the independence of landscape description as a literary form for the first time." (Fitter, 1995, p. 217) Thus, landscape comes into poetry and becomes a record and medium of finely personal affectivity, exhibiting nature penetrated by the poet's soul.

Seamus Heaney (1939-2013) is brought up on the farm in county Derry in Northern Ireland. He lives in the countryside full of natural landscapes during his childhood, which can find full expression in his poetry. "Profound family affections, eloquent landscapes as well as vigorous social concern" (Vendler, 1998, p. 5) are the main themes of his poetry. As far as Heaney's poetic career is concerned, it can be generally divided into three stages. In the first stage, the typical Irish landscape as well as ancient tradition is presented. As the escalation of sectarian and political conflicts between Catholics and Protestants in Northern Ireland at the beginning of 1970s, Heaney begins to search for the root of violence from topographical myth and ancient Irish religious rites in the newly-created collections. 1980s witnesses the development of the third stage in his poetic career known as philosophical stage in which Heaney created many philosophic poems to indicate the universal significance from the perspective of local view instead of direct involvement in political and sectarian conflicts in Ireland.

This paper explores the landscape in Heaney's poetry of first stage, including the collections of Death of a Naturalist (1966), Door into the Dark (1969) and Wintering Out (1972). The publication of his first collection Death of a Naturalist begins with the first stge. The poems in this stage mainly focus on the description about his childhood memories as well as experiences in Mossbawn including natural landscape description in Northern Ireland ( bog as most typical representation), and longstanding farm-practices of his family, his ancestors as well as his neighbors (such as the turf digging of his grandfather, potato digging of his father, milk churning of his mother, ancient skills of the Blacksmith ), and place names(such as "Anahorish", "Broagh" and so on). In Sense of Place, Heaney thinks that "the landscape was sacramental, instinct with signs, implying a system of reality beyond the visible realities.”(Heaney, 1980, p. 132) Anthony Bradley has also asserted the implying meaning of landscape in Heaney's poetry: "In Heaney, the Irish landscape is inseparable from language, from the etymology and music of place names, from work both agricultural and artistic, from history both archeological and 
contemporary; landscape is inseparable, too, from the present political conflict as well as from an atavistic sense of nature as religion and work as ritual; it is inseparable, finally, from the community as divided and the community as unified." (Bradley, 1983, p. 3) Therefore, the landscape description in Heaney's poetry is not only a way of nostalgia for the disappearing Irish natural landscape, but also contribute to deal with writer's relationship with homeland and home culture, expressing his ambivalent feeling of being allied as well as alienated toward native traditional culture. Meanwhile, the landscape descriptions are treated as a retreat for Heaney to reconcile conflicts and keep a proper balance between artistic freedom and social responsibility.

\section{Landscape of Natural Ecology}

Emerson once said: "Study Nature. Know Thyself." (Potts, 2011, p. 189) It implies the importance of nature as well as the relationship between nature and self. In poetic practices, Seamus Heaney actively involves in ecological nature and presents it as vivid landscape description. Heaney is brought up in a family residing in the remote countryside called Mossbawn. Many early poems of Heaney are rooted within specific rural landscape in Northern Ireland. Landscape with natural perception in his poetry is a viable and strategic means of expressing his feeling as well as approach to artistic freedom.

The landscape description of Mossbawn is prevalent when Heaney recalls his hometown and childhood experiences. He remembers when he "got lost in the pea-drills in a field behind the house", then went into the place with "a green web, a caul of veined light, a tangle of rods and pods, stalks and tendrils, full of assuaging earth and leaf smell, a sunlit lair." (Heaney, 2002, p. 3) The peaceful natural description here is a consolation for Heaney. When he gets lost it provides a warm shelter for him, meanwhile the reappearance and reemergence of childhood memory about detailed landscape also offer him a retreat from the Troubles. It implied that if he goes astray or gets lost in the way of artistic career, it is natural landscape that he turns to for help, consolation as well as shelter. In addition, natural landscape can give Heaney varied life experiences, he feels "at the heart of a different life" when he in the throat of a hollow willow tree at the end of the farmyard, which helps Heaney gets acquaintance with the world and his position in the world: "in that tight cleft, you sensed the embrace of light and branches, you were a little Atlas shouldering it all, a little Cerunnos pivoting a world of antlers." (Heaney, 2002, p. 4) However, as Heaney says: "for if this was the country of community, it was also the realm of division" (Heaney, 2002, p. 6), "the word 'Mossbawn' shows provincial perspective toward historical antagonism: Moss, a Scots word probably carried to Ulster by the Planters, and bawn, the name of the English colonists gave to their fortified farmhouses... Yet in spite of the Ordnance Survey spelling, we pronounced it Moss bann, and ban is the Gaelic word for white. So might not the thing mean the white moss, the moss of bog-cotton?" (Heaney, 1980, p. 35) Parker also writes: "the very name of Mossbawn, with its Scots/English/Gaelic etymology serves as an emblem of 'the split culture of Ulster', the Irish paradise seized and 'translated' by the alien Planters." (Parker, 1993, p. 7)

In Mossbawn, Heaney recalls Moyola River, Grove Hill, Aughrim Hill, Lough Berg, and bog which are the typical as well as main geographical characteristics in Northern Ireland, meanwhile can find full expression in his early poetry.

In Heaney's early poetry, Irish Lough landscape is fully presented in the poem of "A Lough Neagh Sequence" and "Relic of Memory". In the seven-poem "A Lough Neagh Sequence", Heaney presents the Lough Neagh with fishermen, creatures such as eels, and the sum total of waters instead of the peaceful lake itself, which shows the distinct characteristic of Irish landscape. The Lough Neagh is a miniature of real society which is full of overpowering natural forces, mystery and instinct: "eels are drawn instinctively from their spawning grounds thousands of miles away in the Sargasso Sea, which seems controlled by some a gravitational force" (Heaney, 1998, p. 45); the eel "describes his arcs without a sound" (Heaney, 1998, p. 32); the other goes "whim deliberately" in their way of returning to spawning ground "where she's lost once she lays / ten thousand feet down in / her origins" (Heaney, 1998, p. 34); the natural cyclicality of fishermen's life; worms "whirling their mud coronas/ under dewlapped leaf and bowed blades" and "making the globe a perfect fit" (Heaney, 1998, p. 31); "the gulls fly and umbrella overhead/ Treading air as soon as the line runs out/ Responsive acolytes above the boat". (Heaney, 1998, p. 32) The detailed description of activities in the Lough Neagh makes the transient events with obvious Irish characteristic eternal to freeze daily work in Lough into cultural heritage, which is a effective way to reserve and pay tribute to Irish tradition.

However, darkness, mystery and uncertainty appear in the wood landscape of the poems "The Plantation", "The Peninsula" and "Night Drive". Maxwell describes the poem "The Plantation" as "a fable of a threatening wood" (Maxwell, 1986, p. 21). Heaney expresses his alienation by spatial disorientation as well as strangeness. The lavish wood landscape brings reader into a world of fear, darkness and uncertainty: "Any point in that wood / 
Was a center, birch trunks / Ghosting your bearings / Improvising charmed rings / Wherever you stopped." (Heaney, 1998, p. 38) Moreover, the personal experience in this wood landscape becomes disoriented: "Though you walked a straight line / It might be a circle you travelled / With toadstools and stumps / Always repeating themselves / Or did you re-pass them?" (Heaney, 1998, p. 38) In the poem, Heaney avoids expressing the fears as well as uncertainty directly by using "you" and "they" instead of "I". In this way, Heaney transforms the personal uncertain and fearful feeling into the experiences of all readers, then into a universal truth. The private thought of frightening and alienation continues in "The Peninsula". Though the landscape is presented here, the poet is not engaged into it. The dislocation is more obvious: "When you have nothing more to say, just drive / For a day all round the peninsula" and "now you will uncode all landscapes / By this: things founded clean on their own shapes, / Water and ground in their extremity" (Heaney, 1998, p. 22).

Bog landscape in Heaney's early poetry is the most typical Irish geographical feature, which is the very evidence of his intimacy with Irish land. Bog is prevalent in Northern Ireland, which serves as the museum of recording the Irish history. In Words into Feelings, Heaney says: "So I began to get an idea of bog as the memory of the landscape, or as a landscape that remembered everything that happened in and to it. In fact, if you go round the National Museum in Dublin, you will realize that a great portion of the most cherished material heritage of Ireland was 'found in bog'. Moreover, since memory was faculty that supplied me with the first quickening of my own poetry, I had a tentative unrealized need to make a congruence between memory and bogland and, for the want of a better word, our national consciousness." (Heaney, 2002, p. 22) Heaney treats "the bog as an answering Irish myth", (Heaney, 2002, p. 22) wherein there are a great many poems created about bog, and there is a collection of Bog Poems published in 1975, which presents readers a bird-view of Irish bog landscape. "Bogland" is the first poem to describe bog in Heaney's poetry: "We have no prairies / To slice a big sun at evening - / Everywhere the eye concedes to / Encroaching horizon, / Is wooed into the cyclops' eye / Of a tarn. Our unfenced country / Is bog that keeps crusting / Between the sights of the sun. "(Heaney, 1998, p. 41) In the description, the distinct Irish landscape with bog image, "the skeleton of the Great Irish Elk out of the peat", "butter sunk under more than a hundred years", "the waterlogged trunks of great firs" (Heaney, 1998, p. 41)are presented to connect the present with history and to show the long history and national tradition of Ireland. From the very beginning of poetry creation, Heaney has attempted to present Irish tradition as well as history hidden in the daily life. Bog is typical geographical feature of Ireland, which can reserve Irish history. In the poetry, Heaney's concern is not on the treasures in the bog, but on the images which carry on Irish tradition and history, which shows his allied feeling toward national culture.

The frightening landscape in the poem "Death of a Naturalist" underscores the alienation Heaney has experienced in the eyes of a child. In the poem, the idyllic, pleasant rural landscape of Ireland disappears, it becomes the townland with "all year the flax-dam festered", "green and heavy-headed / Flax had rotted there, weighted down by huge sods. / Daily it sweltered in the punishing sun. / Bubbles gargled delicately, bluebottles / Wove a strong gauze of sound around the smell." (Heaney, 1998, p. 5) More terribly, the poet faces the threats from "the great slime kings" [frogs], because they "were gathered there for vengeance and I knew / that if I dipped my hand the spawn would clutch it." (Heaney, 1998, p. 5) Strangeness appears when the poet trespasses into the territory of not his own. This dislocation leads to the alienation which attributes to the death of a naturalist's naïve fascination with edenic rural landscape.

\section{Landscape of Farm Practices}

In addition to natural landscape, the description of farm practices of Heaney's family as well as Irish ancestors in his early poetry constitutes landscapes with distinct Irish characteristics. In the early poetry, Seamus Heaney are greatly influenced by Patrick Kavanagh (1905-1967) who is brought up in the farm family of Northern Ireland. They enjoy the similar family background and life experiences. Kavanagh has advocated that poetry should present the local characteristics as well as unique experiences and focus on the field of daily life, folk legend, which is inherited by Heaney. Just as Kavanagh, Heaney chooses "pen" as the tool to inherit Irish tradition, meanwhile continue his consciousness for the countryside and land.

The turf digging of his grandfather, potato digging of his father, milk churning of his mother, ancient skills of the Blacksmith are vividly described to present readers the landscape of farm practices of Irish peasants. Fred Chappell once said: "The ageless relationship between poetry and farming has always been sentimental and ironic, the two disciplines would seem to have mostly accidental requirements in common: patience, fatalism, renunciation, awe of nature, reverence for the earth."(Chappell, 1993, p. 74) Chappell expresses the internal relationship between poetry creation and farm practices, which is a very evidence of Heaney's poetry's inheritance of farm practices of his ancestors. 
The first poem "Digging" in the collection "Death of a Naturalist" describes the farm practices of Heaney's father and grandfather, presenting a distinct landscape of "potato-digging and turf-digging" exactly: "My father, digging. I look down / Till his straining rump among the flowerbeds / Bends low, comes up twenty years away / Stoop in rhythm through potato drills / where he was digging. / The coarse boot nestled on the lug, the shaft / Against the inside knee was levered firmly. / He rooted out tall tops, buried the bright edge deep"... "My grandfather cut more turf in a day / Than any other man on Toner's bog. /Once I carried him milk in a bottle / Corked sloppily with paper. He straightened up / To drink it, then fell to right away / Nicking and slicing neatly, heaving sods / Over his shoulder, going down and down / For the good turf. Digging." (Heaney, 1998, p. 3) Potato and turf are the most suitable representations of Irish tradition because they are the stable grain as well as fuel ancestors of Irish peasants rely on, meanwhile the grantee of their life continuity. Father "levered the shaft firmly" to dig potatoes and grandfather "cut more turf, nicking and slicing neatly" (Heaney, 1998, p. 3). The series of detailed description of farm practices landscape is a very evidence of Heaney's inheritance of Irish history by poetry creation. At the end of the poem, Heaney says: "I've no spade to follow men like them. / Between my finger and my thumb / The squat pen rests. / I'll dig with it." (Heaney, 1998, p. 4) Here Heaney uses the analogy of "pen" with "spade" to show his intimacy with land, to inherit the tradition of ancestors, to dig the ancient national identity, and to spread Irish culture. The action of "digging" exists forever; the tradition of farming is passed down from grandfathers to fathers, then to Heaney, from generations to generations. Moreover, Heaney equals the farm practices of ancestors and family with his work of digging into "living roots" of the landscape, awakening the past, making memories similar with "The cold smell of potato mould, the squelch and slap / Of soggy peat, the curt cuts of an edge." (Heaney, 1998, p. 3) The poem "Follower" also presents the plough landscape of Heaney's father: "My father worked with a horse-plough, His shoulders globed like a full sail strung / Between the shafts and the furrow. The horses strained at his clicking tongue. / An expert. He would set the wing / And fit the bright steel-pointed sock. / The sod rolled over without breaking. / At the headrig, with a single pluck / Of reins, the sweating team turned round / And back into the land. His eye / Narrowed and angled at the ground, / Mapping the furrow exactly." Seeing the scene of father's farming, Heaney "wanted to grow up and plough, / To close one eye, stiffen my arm." (Heaney, 1998, p. 10) In this poem, "father" and the "farm practices of father" can be treated as Irish tradition; the image of "the poet followed horse-plough father" is exactly the Heaney's inheritance of Irish tradition. In Heaney's early poetry, poetic lines are full of various craftsmanship, such as digging, ploughing, churning, thatching, cattle-raising, blacksmithing, divining and so on. By extolling the artisans and describing their crafts, Heaney helps them establish their place in Irish tradition, and let them alive forever in the poetry. As Parker describes: "The frequent tributes in poetry and prose to neighbors from his home ground reveal the debt he feels he owes to them, and his desire to fuse his achievements to theirs." (Parker, 1993, p. 5) Heaney's detailed description of farm practices landscape confirms the analogy between farming and writing: writing is not a cerebral and academic activity, but also equates with farm practices, which physical power, courage as well as intelligence are required. Just as potato is served as stable grain, turf as fuel for Irish peasants, poetry creation helps sustain and develop the land of Ireland, making its tradition as well as spirit eternal. As the digging "going down and down", poetry creation will continue, and both of them constitute parts of Irish tradition.

However, the landscape of farm practices in Heaney's early poetry also indicates his alienation from home culture and tradition. Ian Hamilton wrote: "At its freshest, it conveys a country-boy's first troubled encounters with sexuality, responsibility, and death; at its most pious, a merely sentimental affection for a disappearing, peasant-simple world. Beyond the rustic homage can be glimpsed Heaney's anxiety about how he can best keep faith with the values of his tribe and ancestors while not lapsing into their grunting curtness and silence." (Hamilton, 2000, p. 1918) His remarks is a fully expression of Heaney's ambivalent feeling towards home culture as well as Irish tradition, which can find full expression in landscape of farm practices.

Heanney's catholic family and tribe is the origin of alienation, and his educational experience furthers the division. Heaney thinks this education experience leads to the "consciousness and quarrels with the self... what Lawrence called 'the voices of my education' at odds with ancestral voices: Those voices pull in two directions, back through the political and cultural traumas of Ireland, and out towards the urgencies of the world beyond it. At school I studied the Gaelic literature of Ireland as well as the literature of England, and since then I have maintained a notion of myself as Irish in a province that insists that it is British. Lately I realized that these complex pieties and dilemmas were implicit in the very terrain where I was born." (Heaney, 2002, p. 40) As a matter of fact, Heaney's education experience can be treated as "exile from Mossbawn", which offers his ambivalent feelings toward home land and home culture.

Through the landscape in "Digging", alienation is indispensable though he is unwilling to admit the fact and tries 
his best to avoid it. He has "no spade to follow men like them [his father and grandfather]" (Heaney, 1998, p. 3), he will dig with the pen instead. Actually, in his age of being able to carry out farm practices, Heaney leaves for studying and boards at school. In this sense, he has not actually engaged in farming activities. He once told Thomas O'Donnell in an interview at the year of 1983: "I didn't work, say, from eighteen to twenty four on the farm. I was constantly on the conveyor belt of colleges and schools. Then I taught when I finished my degree in Belfast. So in a sense I didn't actually work on a farm, except I grew up there and took part in the activities." (O'Donnell, 1983, p. 64) His taking part in the activities is only confined to "listening" (Under my window, a clean rasping sound / When the spade sinks into gravelly ground: / My father, digging.), "watching" (his straining rump among the flowerbeds / Bends low, comes up twenty years away / Stooping in rhythm through potato drills / Where he was digging.), "picking"(new potatoes), "carrying milk" (for grandfather). Moreover, other artisans in Heaney's description are romantic and dreamy figures alienated from Heaney's world.

Therefore, landscape of farm practices in Heaney's early poetry shows Heaney's ambivalent feeling about home culture. He is both allied and alienated with his home culture and Irish culture.

\section{Landscape of Place-Names}

Another way Heaney expresses his feeling towards home culture is the landscape of place-names, which contents many mythological-toponymic tales. These poems belong to the tradition Irish genre of the dinnseanchas. It is a genre which conceptualizes a human being's relationship with a place through historical events or mythological tales. Heaney considers dinnseanchas "relate the original meanings of place names and constitute a form of mythological etymology." (Heaney, 1980, p. 131) Welch affirms the implications of place-names in Ireland: "land of Ireland is perceived as being completely translated into story." (Welch, ed. 1996, p. 150) Michael further explains: "these are collections of sacred stories (Irish, senchasa), written down in verse and prose from $\mathrm{AD} 1160$ onwards using archaic oral sources, explaining the origin of noteworthy Irish place-names, or dind." (Welch, ed. 1996, pp. 14-15) Michael also gives its definition: "a place-name is derived from the adventures of a deity that come to a climax at a particular spot, often involving the death of the prototypical being. By this means places come to be regarded as place-events. Without this Happening, the place would cease to exist. Therefore the god and the man do not die in vain. Together they help to make reality for later generations. " (Welch, ed. 1996, p. 117) In this sense, the place as well as landscape are the expression of supernatural force. The geographical features, regional landscapes are endowed with the extensive cultural, historical and mythical meaning, which meanwhile helps to express certain ideology. And the related stories as well as legends are passed down from generations to generations.

Heaney points out: "Over time and because of natural forces and human presence transforming the landscape, we just might have lost the 'skill to read' these meanings, while a 'natural feature' that endowed a place with its name may remain." (Heaney, 2002, p. 132) Room considers: "In many locations the original feature that gave its name to the place will have been obliterated or lost, especially if the site has developed into a town or city...[Lakes] can dry up or be drained, woods are thinned and cut down, fords are replaced by bridges, and rocky landscapes are leveled. When this happens, a place-name that was originally simply descriptive becomes historic, reminding us today that once, long ago, this is how the place was seen by the people who named it." (Room, 1988, p. 10) However, the situation is different in Ireland. "Seemingly outdated place-names readily survive in Ireland, because in general they are names not of settlements and other visible components of the landscape but of small land units known as townlands into which, since at least the Medieval period, every country and parish has been divided, and which at an early date gained legal and therefore lasting significance." (Room, 1988, p. 93)

In the early poetry, Heaney combines the fields and townlands into "the histories of its owners. Broagh, The Long Rigs, Bell's Hill; Brian's Field, the Round Meadow, the Demesne; each name was a kind of love made to each acre. And saying the names like this distances the places, turns them into what Wordsworth once called a prospect of mind. They lie deep, like some script indelibly written into the nervous system."'(Heaney, 2002, p.6)

In the poem "Anahorish", Heaney combines the landscape, tradition and ancestors' activity into the place. Anahorish, "place of clear water", is the place where Heaney has spent most of his childhood. It is full of idyllic scenes: "springs washed into / the shiny grass / and darkened cobbles / in the bed of the lane." The wonderful rhyme is related to the sweet memory: "Anahorish, soft gradient / of consonants, vowel-meadow, / after-image of lamps / swung through the yards / on winter evenings." (Heaney, 1998, p. 47) Then the bucolic landscape reminds the poet of the non-violent Irish tradition and the simple and unsophisticated activities of ancestors "With pails and barrows / those mound-dwellers / go waist-deep in mist to break the light ice / at wells and dunghills" (Heaney, 1998, p. 47), which is a good way to inherit and extol Irish traditional culture. 
The landscape of place-names also provides Heaney a retreat. Sidney Burris considers deeper implication in Anahorish: "Heaney imagines that the name itself possess ineffable powers of cultural sovereignty. Irish place-names in the United Kingdom become for Heaney subversive incantations that both glorify his Celtic lineage and establish its integrity in British Northern Ireland. The poem dexterously appropriates a landscape politically British in its legal demarcation but linguistically Irish in its nomenclature." (Burris, 1990, p. 12) In Heaney's lecture "Place and Displacement: Recent Poetry of Northern Ireland," it expresses the clearest statement about the direction of his poetry. Referring to the political situation in Northern Ireland, Heaney suggests that in the face of such an intolerable reality, "the poet's artistic drive... is to move to a higher level of consciousness and resolve the conflict symbolically in art... The contemporary poet in Ireland is compelled to 'outstrip' the unbearable political reality of Ulster, to transcend it in highly formal lyrics, to enter the linguistic mode of play that momentarily intensifies him and detaches him from his predatory circumstances." For Heaney, "the poetic transcendence is not an evasion of sympathy with national conditions but rather a transposition of that sympathy into symbol." (Schuchard, 1990, p. 6) Heaney's own way of landscape description, represents the wish that not only resistants to the order that has been but an imaginative establishment of a new order that transcends the dichotomies of the old ones. In "Toome", when pronounced, the "soft blasting" explores a "souterrain under the dislodged / slab of the tongue" and goes into an old realm of "loam, flints, musket-balls, / fragmented ware, / torcs and fish-bones." (Heaney, 1998, p. 143) Elmer Andrews considers that in the poems of place-names, "the colonial influence is responsible for replacing a pleasure, easy-going warmth with authoritarian stiffness, feeling with reason, instinct with efficiency, freedom with coercion, the organic community with violence and alienation" Andrews thinks that Heaney "yields to the Rousseauesque dream of an innocent language and community untouched by the evils of progress, a mythology of presence, which ignores the self-alienating aspect of any language and all social existence." (Andrews, 1988, p. 59) Therefore, in the poems of places-name, Heaney combines the landscape, history into the place of poems to express his feelings and to negotiate an undeniable cultural intersection which can solve the conflict effectively.

\section{Conclusion}

The landscape description endows the countryside with the maternal, sustaining qualities that describe the traditional pastoral refuge, the retreat from the hustle and bustle of daily life that encourages philosophical detachment. Once again the landscape of rural Ireland is not so much a retreat from reality as another means of confronting it. Heaney's sense that landscape is a viable means of finding this freedom governs his own poetic approach to balance between artistic freedom and social responsibility. He has referred to the landscape around his family farm where he grew up as a retreat where he is given a space of his own to concentrate on artistic creation; meanwhile it is treated as a way to express his ambivalent feeling towards home culture, allied or alienated.

\section{References}

Aalen, F. H. A. (1978). Man and Landscape in Ireland. London: Academic Press.

Andrews, E. (1988). The Poetry of Seamus Heaney: All the Realms of Whisper. New York: St. Marin's Press.

Bradley, A. (1983). Landscape as Culture: The Poetry of Seamus Heaney. In J. D. Brophy \& R. J. Porter (Eds.), Contemporary Irish Writing. Boston: Twayne.

Burris, S. (1990). The Poetry of Resistance: Seamus Heaney and the Pastoral Tradition. Athens: Ohio University Press.

Chappell, F. (1993). Plow Naked. Ann Arbor: University of Michigan Press.

Fitter, C. (1995). Poetry, Space, Landscape: Toward a new Theory (p. 217). Cambridge: Cambridge University Press.

Hamilton, I. (2000). Oxford Companion to $20^{\text {th }}$ Century Poetry. Oxford: Oxford University Press.

Heaney, S. (2002). Finders Keepers: Selected Prose 1971-2001. London: Faber and Faber.

Maxwell, D. E. S. (1986). Heaney's Poetic Landscape. In H. Bloom (Ed.), Seamus Heaney. New Haven: Chelsea House.

O'Donnell, T., \& Campbell, D. (1983). Interview. Cottonwood, (30), 62-74.

Parker, M. (1993). Seamus Heaney: The Making of the Poet. Iowa City: University of Iowa Press.

Potts. D. L. (2011). Contemporary Irish Poetry and the Pastoral Tradition. Columbia and London: University of Missouri Press. 
Room, A. (1988). A Dictionary of Irish Place-Names. Belfast: Appletree Press.

Schuchard, R. (1989). Introduction to the Place of Writing, by Seamus Heaney. Atlanta: Emory University Press.

Siddal, S. (2009). Landscape and Literature. Cambridge: Cambridge University Press.

Vendler, H. (1988). Seamus Heaney. Cambridge: Harvard University Press.

Welch, R. (Ed.). (1996). Dinnshenchas. Oxford Companion to Irish Literature. Oxford: Clarendon Press.

—. (1980). Preoccupations: Selected Prose 1968-1978. New York: Farrar Straus.

—. (1998). Opened Ground: Selected Poems 1966-1996. New York: Farrar Straus.

\section{Copyrights}

Copyright for this article is retained by the author(s), with first publication rights granted to the journal.

This is an open-access article distributed under the terms and conditions of the Creative Commons Attribution license (http://creativecommons.org/licenses/by/3.0/). 